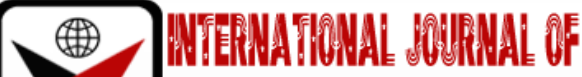



ISSN 2278 - 0211 (Online)

\section{Use of Sustainable Non-Contemporary Materials by East African Multi-Disciplinary Artists: Case of Sanaa Gateja, Evans Ngure and Samson Ssenkaaba}

\begin{tabular}{|c|}
\hline Wanjiku Angela Murigi \\
Postgraduate Student, School of the Arts and Design, \\
University of Nairobi, Kenya \\
Dr. Samuel Mwituria Maina \\
Senior Lecturer, School of the Arts and Design, \\
University of Nairobi, Kenya
\end{tabular}

\begin{abstract}
:
Many states across the world have adopted the 2030 Agenda for Sustainable Development and the Sustainable Development Goals (SDGs). The purpose of these goals is to realize a sustainable future for all. This is further expounded upon as upholding of human dignity, social inclusion and environmental protection (UNESCO, 2016). In furtherance of these goals, artists, architects, designers and those in the creative space in East Africa are embracing this call though their artwork and their production processes. This paper studied three champions of such creative's through a multiple case research design in Nairobi. The aim was to establish their approach to application of east African domiciled cultural techniques and materials to produce contemporary art and design. The study concluded that east African art and design has pervaded and surpassed all colonial, national and international boundaries. The Impact is manifested in the fact that through the years, east African art \& design has become collected artifacts in countries where it has been exhibited.
\end{abstract}

Keywords: East Africa, art and design, contemporary, multidisciplinary, materials

\section{Introduction}

Contemporary African art is popularly defined as art made by African artists in Africa and the diaspora in the era of post-independence. Many people with diverse backgrounds are involved in this field. A growing number of East African artists are addressing sustainability issues of grassroot democracy, social justice, non-violence and ecology. These are not only highlighted as themes in their works but also in their practice of making the artwork.

Being notable, Sanaa Gateja, Evans Ngure and Samson Ssenkaaba are some of the artists in East Africa championing this contemporality. They each uniquely bring their own inimitable style using non-conventional locally available materials to cover their wide range of concepts. These artists not only make positive environmental impact but also provide economic and social impact by involving the people in the communities that they are a part of.

\section{Theory}

\subsection{Sanaa Gateja}

This prolific Jewelry designer, innovator, painter and teacher was born in Uganda in 1950 . He began his professional career in 1968 as an Assistant Crafts Officer at the Ugandan Ministry of Culture and Community Development (Framer Framed, 2015). His dedication to work and devotion to the crafts sector accorded him the opportunity to represent Uganda at the International Expo in Osaka Japan as the manager of the Ugandan pavilion in 1970.

He relocated to Mombasa, Kenya in 1971 and started his Art and Design career. He opened an Art Gallery called Studio Sanaa first at the Old Town and later on Moi Avenue High Street. The gallery exhibited traditional Kenyan arts comprised of Basketry and Jewelry of the East African coast and functional arts of Northern Kenya: Lamu and Somalia (Gateja, 2015). He grew the gallery working in close partnership and collaboration with other pioneer art organizations in Mombasa such as Mombasa Home Industries, Bombolulu and eventually African Heritage in Nairobi.

In 1982, Sanaa sold the gallery and went to university in Florence, Italy at the Universita Internazonale dell Arte (International University of Art) for a diploma in interior design from 1982-1983. He went on to train as a jewelry designer at Goldsmiths, London College of Art and Design. Upon completion of his studies, he worked within the trade, expressing himself creatively by combining jewelry, music and visual art. He was active in participation as a member of the Diaspora artists in the United Kingdom and as member of the British crafts council. He opened Safari Studios at 
Clerkenwell, a jewels section on St. Julius Street. With the Diaspora artists, he was able to hold exhibitions at the African Centre Convent Garden, The Royal Festival Hall South Bank- New Horizons. It was at this venue that Sanaa held The Home Coming art exhibition in celebration of Uganda's liberation in 1986.Three years later, Sanaa found it necessary to move back to Uganda, where he opened the Kwetu Africa Art and Design Centre in Lubowa, outside Kampala.

\subsection{Materials}

As Sanaa taught art classes in London, he found a bead in the rubbish bin that someone identified as a paper bead. Fascinated by the bead he took it home to study it and began to make his own beads. His view of each bead is as small sculpture full of character (Bell-Roberts, 2019). Upon his return to Uganda, he introduced paper beads earning him the nickname 'Bead King'. The beads he made were fashioned from discarded paper. Later he made beads from locally sourced materials such as clay, bark cloth, raffia, wood seeds and banana fiber. Sanaa references to ancient African bead trade, functions of beads as a form of money and wealth and counting and inspiration from the Egyptian culture (Komukama, 2018).

The paper beads are made from salvaged waste printed paper; calendars, brochures, books and political posters. The paper is cut up into strips, rolled up tightly into tubular beads, glued and then varnished.

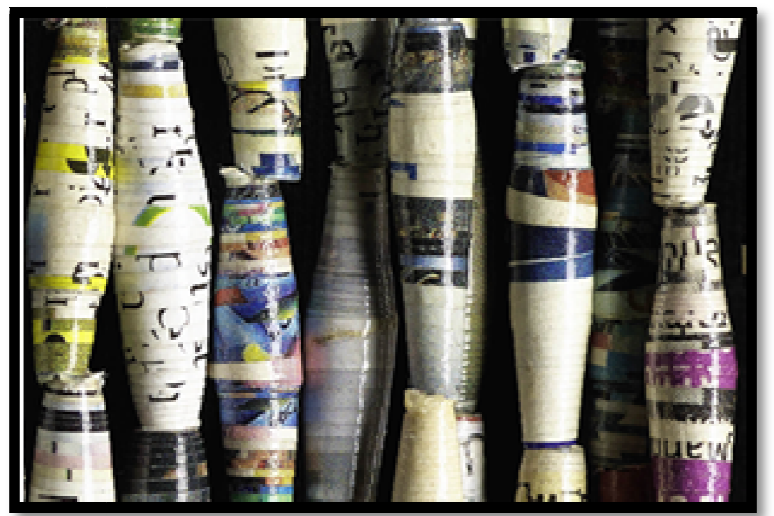

Figure 1: Paper Beads with Visible Print Letters Source:Https://Www.Sanaa-Gateja.Com/

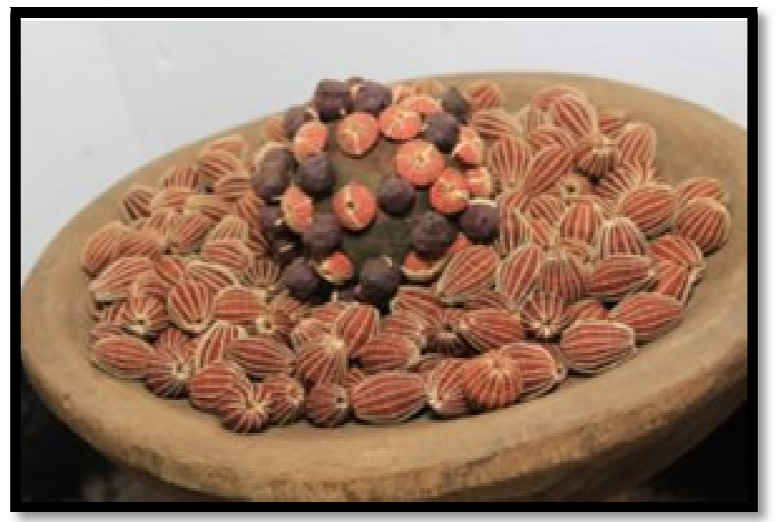

Figure 2: Bark Cloth Beads Decorated with Raffia Source: https://www.sanaa-gateja.com/

This process produces thin beads. Rounder and thicker beads are made by compressing paper and gluing it to the outside surface similar to papier mâché (Gateja, 2015). This process is also applied when using banana fibre and bark cloth, a tree fibre.

\subsection{Artwork}

Sanaa's attitude towards beads and the extraordinary relationship with the materials he uses allows him to channel out his creativity as a multidisciplinary artist. His work includes installation pieces in tapestry, sculpture and bead wear and accessories. His pieces achieve aesthetic and conceptual value as commentaries of social and environmental expediency. He channels present and past personal and societal experiences (Kayem, 2018).

One of his most prolific tapestries is CHANGE, (Error! Reference source not found.). It was made form discarded press material from the 2008 Obama Presidential Campaign. The project was done in collaboration with American artist Algernon Miler. The wall piece was exhibited at the

Museum of Art and Design in New York. Some of his other notable abstract tapestries are Yonder (2019), Blue mood (2018), White mood (2018) Success (2016) among others done in captivating multicolor designs, with beads on bark cloth. 
For his paintings he uses bark cloth rather than the mainstream canvas. The paintings have multiple surface textures achieved by the use of a variety of beads. The Kenya fashion awards have showcased Gateja's work on the runway. For fashion, he makes beaded shawls, yoke fashioned neckpieces, beaded bags, clutches and belts. The crafts also include home accessories such as table and floor mats. These are popular with the European market.

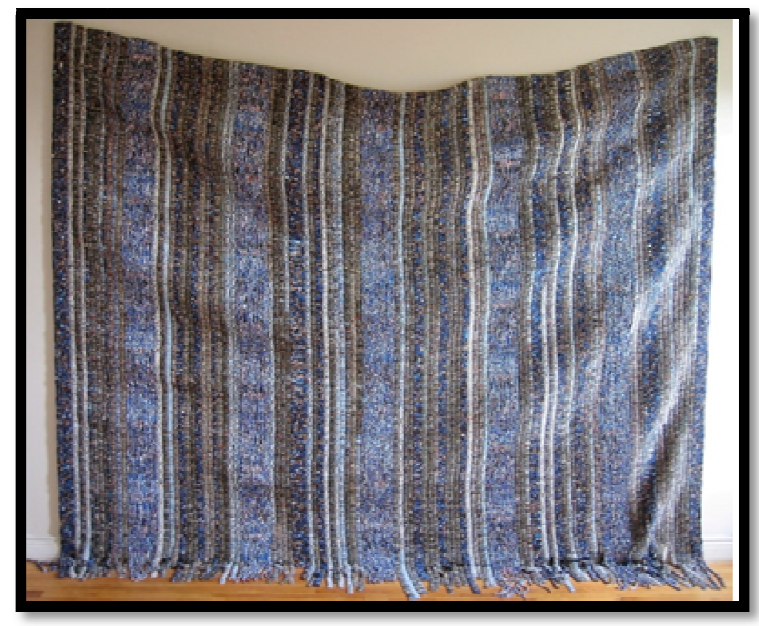

Figure 2: The Change Tapestry

Source: http://mackayinuganda.blogspot.com/

\subsection{Exhibitions}

As one of East Africa's pioneer artists his work is on permanent display at the National museums of Kenya, Uganda and other parts of the world. Sanaa has showcased at Latitudes Art fair (2019), Art X Lagos (2019), ARCOlisboa (2019) FNB

Johannesburg Art Fair (2018, 2017, 2016), AKAA Art Fair, Paris (2018, 2017, 2016) and Art X Lagos (2018), Paths: An Exhibition by Sanaa Gateja - Village Mall, Bugolobi (2016), Memories - AfriArt Gallery, Kampala(2015), Art Safari, and Lubowa(2015)

\subsection{Impact}

By promoting the art of bead work among communities in Uganda Kwetu Gallery and Sanaa, Gateja have contributed to poverty alleviation. The skill is now practiced by over 50,000 people in various communities as stated by Sanaa during an interview with CNN(Gateja, 2015). Through his work, he continues to highlight the importance of recycling in the current eco-conscious world.

\section{Evans Ngure}

\subsection{About}

Evans was born in 1989 in Nairobi, Kenya. His interest in art started at an early age with his father playing a great role in it. He accompanied him to jua kali (Informal) mechanic workshops in Kariokor and Ngara where he got his Peugeot pick-up fixed up. Here he would tinker with the hand tools and vehicle spare parts, fashioning trucks from the parts. He sketched cartoons and political figures inspired from newspaper images. His first drawing of a car was an assignment from his father (Gacheru, 2018).

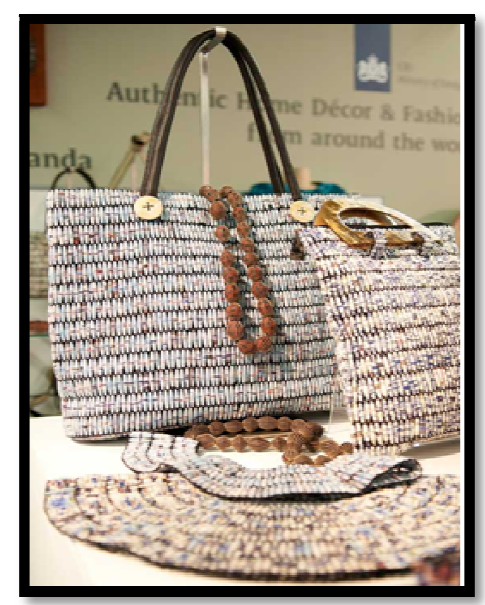

Figure 4: Paper Bead Bags and Neck Pieces on Display Source: Https://Www.Sanaa-Gateja.Com/Accessories 


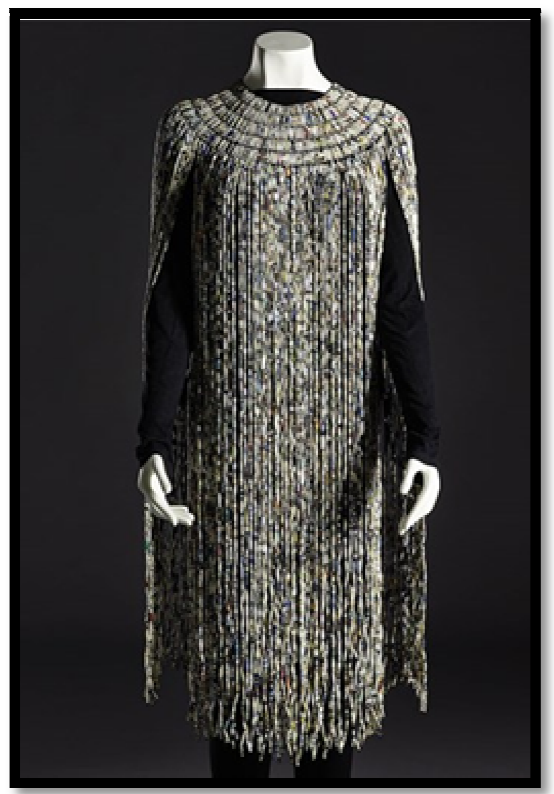

Figure 5: Beaded Shawl by Sanaa Gateja Source: Https://Www.Nms.Ac.Uk/

At Kenyatta University where he studied fine art, he majored in Painting. He honed his skills and gained keener interest for sculpture. Anne Mwiti, his lecturer encouraged him to work with non-traditional materials for his art. He has since developed his artistic expression of found objects (Anne Mwiti, Personal interview).

\subsection{Materials}

Open-minded, Evans explored the new possibilities in materials choice including recycled spare parts as he had done in his childhood. At junkyards, he collected nuts, bolts, spark plugs, wire metals. From Gikomba, he scavenged buttons from the mitumba (second hand) clothes. Currently, he collects from various dumpsites. People also bring him a variety of found objects including old copper coins, bottle tops, beverage cans, zip fasteners and broken utensils. He also mixes up materials to include bamboo, driftwood, copper wire, brass and glass. The latest materials in his workshop are 600 wine bottles and 300 wine corks collected from the 2019 Nairobi Wine Festival (Fig 6) (Ngure, Personal interview).

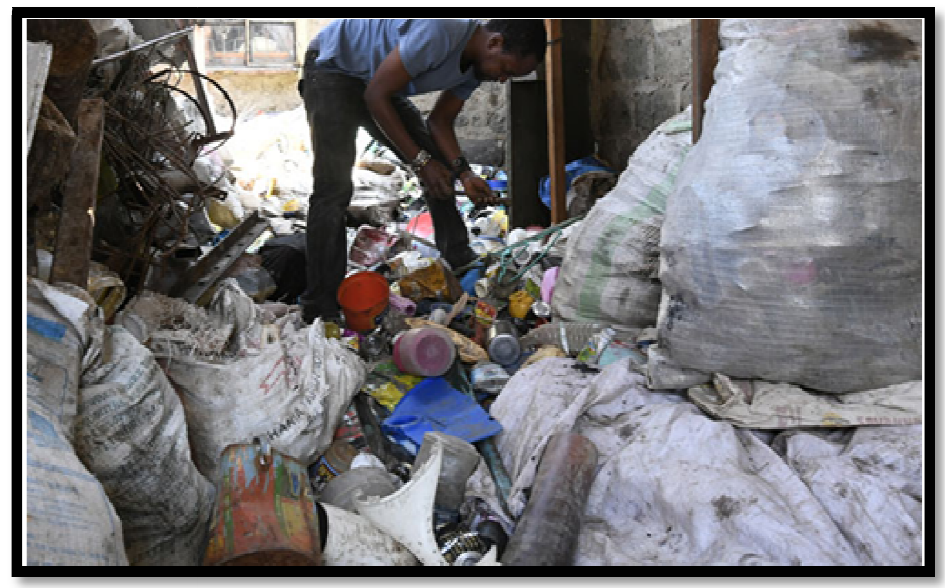

Figure 6: Ngure Scavenging through Waste Source: Https://Www.Ndtv.Com/World-News

The choice of found objects as material for his work makes for inconsistent supply. This however, does not limit his production but challenges him to creative use of the available materials.

\subsection{Art Work}

Ngure draws inspiration from culture, nature and personal events. A recurring factor in his work is the circle. He believes that the circle has some stability and power, signifying a complete life that all people endeavor to achieve. 


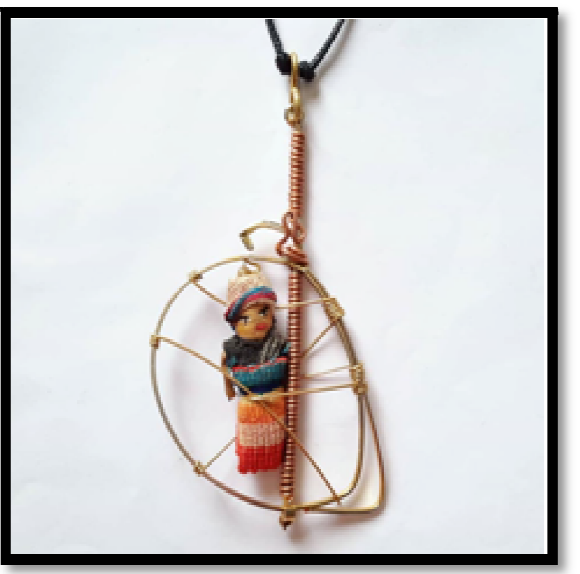

Figure 7: Wearable Art Pendant

Source: https://www.facebook.com/evansmainangure/

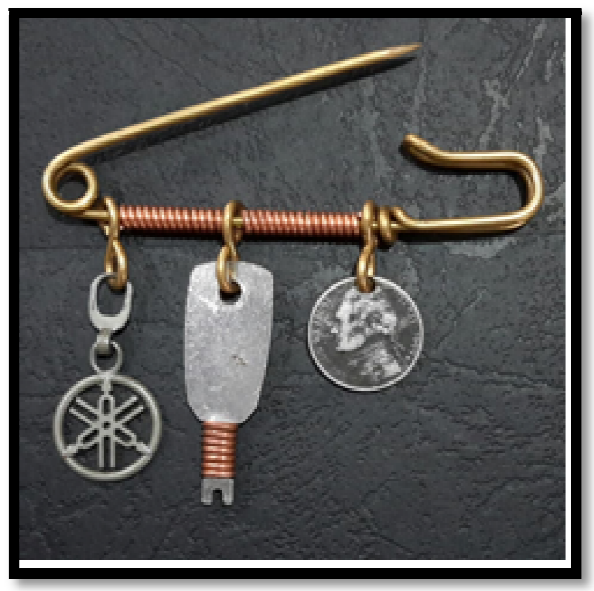

Figure 3: Wearable Art Brooch

Source: https://www.facebook.com/evansmainangure/

His style of inventiveness and artistic ingenuity has propelled him as jewelry and accessory designer and artist. He describes his jewelry as a junk art jeweler. It includes coin earrings, brooches, and necklaces with quirky pendants, ziphandled earrings and leather wrist cuffs. He also makes chokers and dog leashes from leather.

His earlier flat paintings influenced his love for mixed media. He now adds recycled found materials that create unique visual texture. He incorporates aluminum beverage can sheets in his work. His preference for the material is because of its durability, glossy bright colored hues and its eco-friendliness (Ngure, personal interview)

He also makes items for interior spaces such as furniture, wind chimes and accessorized flower pots. For these he uses old cups and kettles as well as wine glass bottles and their corks.

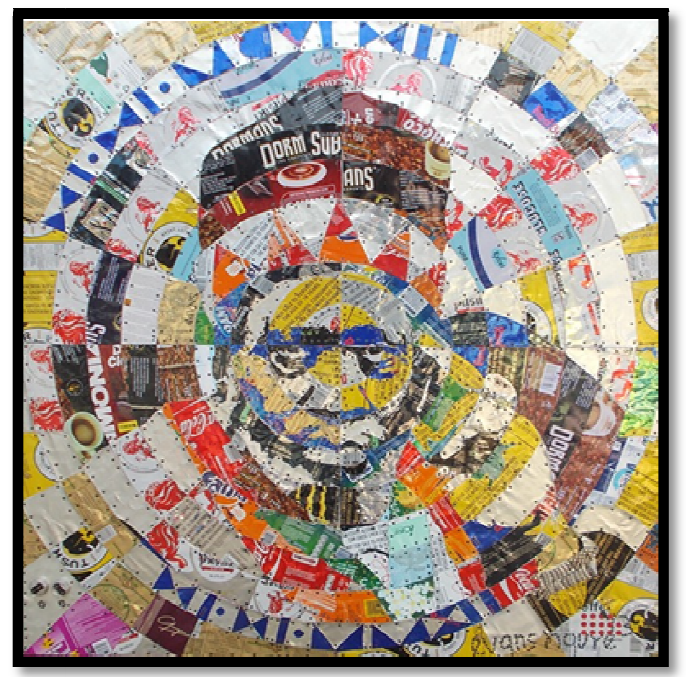

Figure 9: Kenyatta, Aluminum Cans Painting Source: https://www.behance.net/gallery 
Ngure occasionally does installation pieces that address current issues such as global warming and marine pollution. Error! Reference source not found. is an image of the installation piece titled, So Little Time. It is made from found objects assemblage themed on marine conservation and fishing practices. His work is available online, on Instagram, Facebook and even Etsy.com under the username NgureJunkArt.

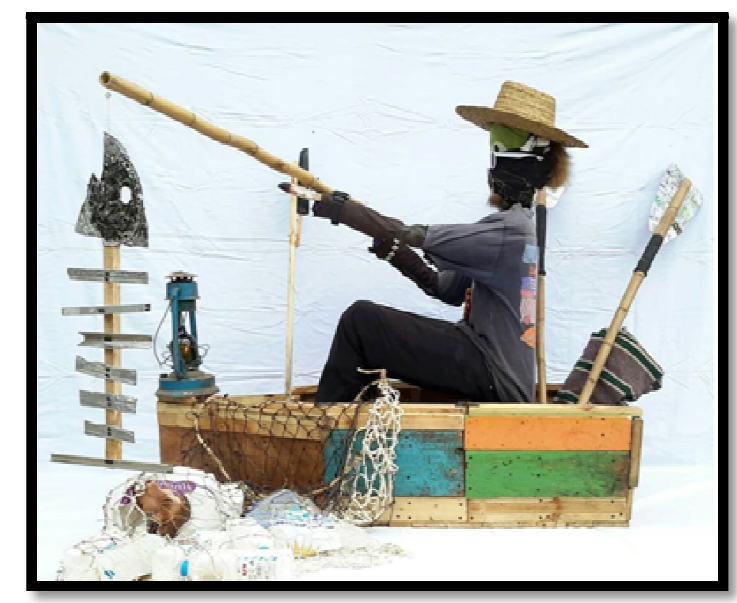

Figure 10: So Little Time (2019)

Source: https://www.facebook.com/evansmainangure/

\subsection{Exhibitions}

His earliest exhibition was in 2011 while he was still a student at university, at the Polka Dot Gallery(Gacheru, 2018). His most recent exhibitions to participate in are; the FORM sculpture exhibition, One Off Gallery, Nairobi (2019), Kenya Art Panorama 70 years, 70 artists, Alliance Françoise de Nairobi (2019), Vanishing Wonders Art Exhibition, Village Market (2019). His worked is featured at annual Affordable art show at the Nairobi National Museum,

\subsection{Impact}

Ngure's motivation to recycle is to raise awareness about conservation of the planet. He makes sizeable contributions from the profits of his exhibitions to this cause. He has raised funds for the conservation of the Nguruman escarpment forest, Kenya, the forest guardians and the community in that area.

He also facilitates workshops with young children. He teaches them about conservation, recycling and upcycling. The highlight of the workshops always is the collages and sculpture pieces the students create from found objects and waste in their schools. He is also involved in the Fashion Revolution. The movement creates awareness about the impact of the fast fashion industry and its practices and proposes the application of slow fashion initiatives.

\section{Xenson}

\subsection{About}

Baptized Samson Ssenkaaba, Xenson, was born in 1979 in Uganda. During his childhood years, Uganda was embroiled in revolution wars. His grandfather and former Ugandan Vice President was a key player in the revolution. Out of the country's political state, Ssenkaaba would recreate scenes of the war with miniature installation of toy soldiers at war, wire cars, trucks, trailers and mambas. These were made from bullet shells and magazines that he collected. He also made war soundtracks with his mouth as he played (africanah.org, 2014).

He pursued his undergraduate degree at the Margaret Trowel School of Industrial and Fine Arts, Makerere University, Kampala, Uganda. This choice was after leaving his engineering studies. His creative influence is from the grandeur of the African arts and cultures, the vitality in African dance and the free expression art form of hip-hop.

\subsection{Materials}

Xenson works with alternative materials. His repertoire of materials includes recycled post-consumer products such as paper magazines, bottles cans, banana peels, and rubber tires. He interplays these materials with organic and natural materials as well as commercial canvas (Personal observation).

\subsection{Artwork}

With great ingenuity and application of ancient African craftsmanship, he creates phenomenal works of art. His artistic expression transcends across disciplines. He expresses himself using installation pieces, films and videos, photography, poetry and performances, fashion and painting. His works feature contemporary themes of consumerism, corruption, immigration, neo-colonialism, multiculturalism, exploitation and material culture. The concept of identity is also common in his work. He adopts masks for his subjects both in performances and on canvas. Through the mask subject, he explores the obscurity of identity. According to Xenson, people wear masks every day. He also questions the complexity in identity of humans in the contemporary time. 


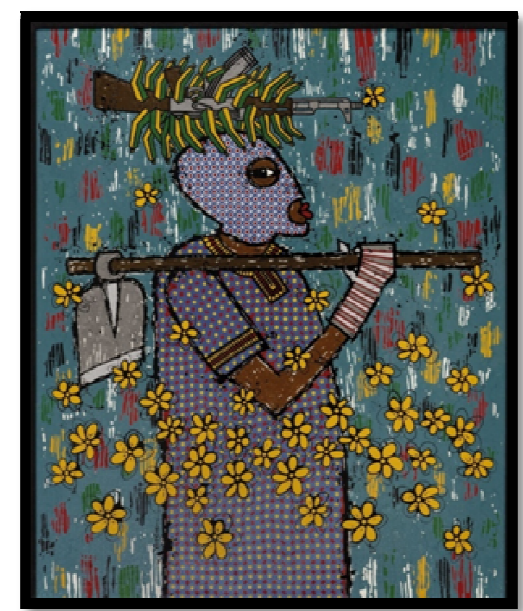

Figure 4: Matoke Farmer (2016)

Source: https://artauctioneastafrica.com/

At a solo exhibition titled exhibition titled GUNFLOWERSMASK held in Kampala in 2017, Xenson presented paintings, installations, photographs and poetry. This showcase was a provocative commentary on life issues such as identity, insecurity and wars. The common features in these works as suggested by the exhibition title were: masks, flowers and guns.

The artwork (Figure 4) is a mixed media on canvas painting from the collection. He uses vivid colors and graphic patterns as in most of his paintings. He depicts a masked subject, a farmer, on whose head, sits a bunch of matoke (green banana) growing from the body of an AK47. In this painting he alludes to the hardship of structural and institutional violence encountered in everyday life.

XENSON is the label of his haute couture fashion line. He makes the costumes from bark cloth, paper beads, rubber tires and tubes. He also hand paints on his choice fabrics. An authentic brand of handbags, shoes and other fashion items

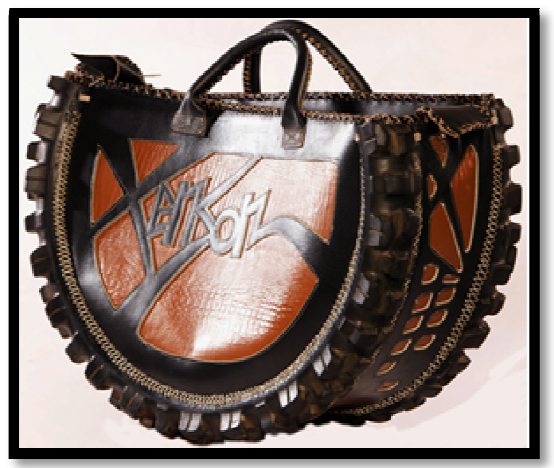

Figure 12: Upcycled XENSON Tire Handbag Source: https://www.africafashionguide.com/

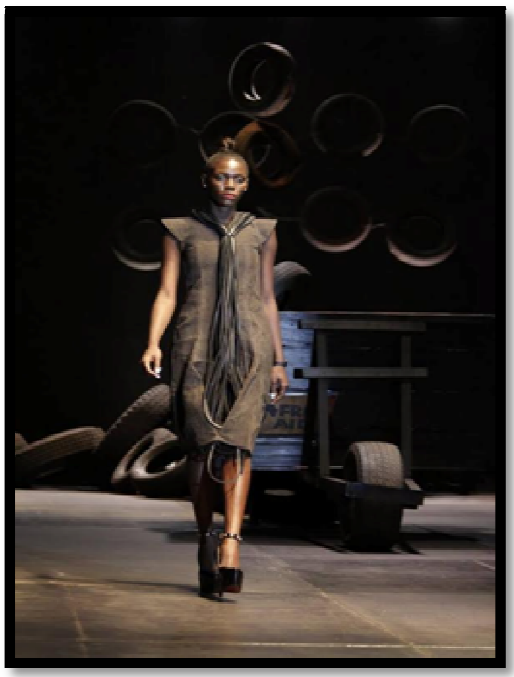

Figure 5: A model walks a XENSON Ensemble Accessorized with Tire Straps Source: https://eagle.co.ug/ 
Accompanying his paintings at exhibitions are some of his poems. A poem scribed on walls at the GUNFLOWERSMAS Kexhibition read, Nze ye Nze/ Gwe ye Gwe/ GwesiNze/ NzesiGwe (loosely translated: I am Me/ You're You/ You're not me/ I'm not You.) (Nsubuga, 2017). Observers of his work describe it as provocative, volatile and extraordinary due to his incorporation of Paintings, poetry and performance art.

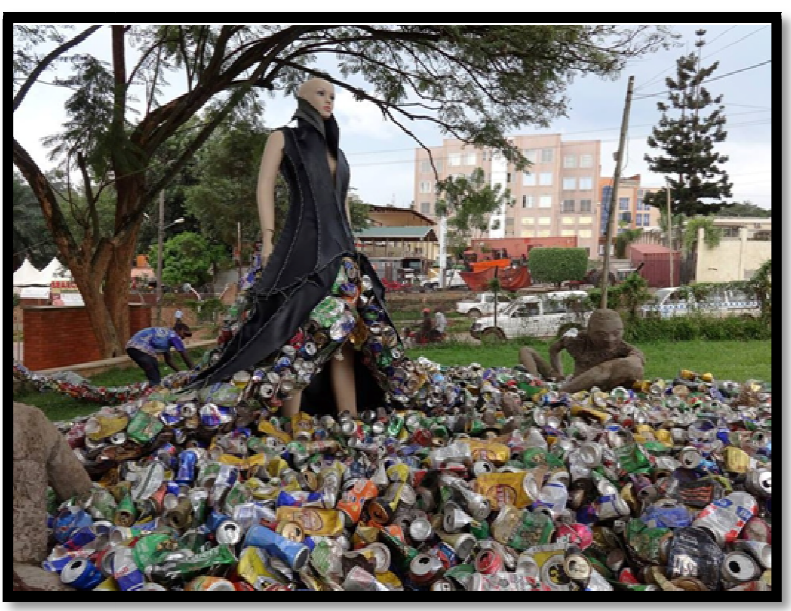

Figure 6: A Xenson Multimedia Installation Source: https://theculturetrip.com/

\subsection{Exhibitions}

Since graduating from Makerere, in 1999, Xenson has made appearances of his Art works, Films and fashions showing at numerous exhibitions and shows in Uganda and abroad. He has participated in workshops, residences and exhibitions including: Gunflowermask, Afriart Gallery, Kampala, (2017)Kabbo ka Muwala, Zimbabwe, Uganda, Germany (2016). Johannesburg Art fair ,South Africa (2015), KLAART Uganda (2014).The Lubare and the boat, Deveron Arts Scotland (2014).Institute Buena Bista, Curacao (2014), Future of Africa summit, Paris, France , Africa now: Fashioning person hood, Minneapolis Institute of Art, USA ( 2014), Artist in Residence, 32 Degrees East / Uganda Arts Trust, Kampala (2013) KLAART Kampala, Uganda (2012), World Cultural Forum, Rio de Janeiro, Brazil ( 2016)(Kampala Art Biennale, 2018)

\subsection{Impact}

Through the years Xenson has become a collected artist in countries where he has held exhibitions such as: Germany, Scotland, United Kingdom, Netherlands, Brazil, Argentina, France, USA, Canada, Niger, Burkina Faso, Kenya, Tanzania, Rwanda and Uganda.

One of his beliefs is that 'African culture is nothing without community and to develop Africa, you need to involve the community.'He teams up with local women to hand-weave items from organic cotton, make paper beads and to tie-dye clothes. Through these activities, the women are able to earn a living. This fact brings Xenson great fulfillment. Xenson is also passionate about giving back to the Ugandan community. Through his Art-Club, he promotes and teaches to students and persons with or with no artistic background.

\subsection{The scope of the Study}

The study was domiciled in Nairobi, Kenya. Key informers from the wider East Africa were contacted and interviewed. The study confined itself to the art and design of the geographical area shown in the map. It took twelve weeks while confining itself to fine art, design, artifacts and not music or performing arts.

\section{Methods}

This study applied a multiple case study research design. Three prominent east African artists were selected. They were selected randomly based on the presence on literature in the geographical area of the researcher. Online presence was also accessed and found to be extensive enough to support a study of their pieces. Where available, the researchers visited several art galleries to check-up the presence or otherwise of the art pieces. Key informants were also contacted to shed light on their scope of knowledge of the three artists. The results were presented and discussed in class setting at masters' level and discussed with lecturers and invited artists and collectors. The results were analysed using online transcription tools and presented in text and pictorial formats.

\section{Discussion}

The findings support the definition that contemporary African art is art made by African artists in Africa and the diaspora in the era of post-independence. With the three case studies being domiciled in the east Africa region, it is evident that they are influenced by their upbringing and their living environment. Use of recycled and found objects runs in their styles. The fact that the trio, Gateja, Sanaa and Ngure have exhibited in traditional east African arts galleries attests to their influence in their respective genre and east Africa art scene in general. 
The trios' creative influence is obtained from the grandeur of the African arts and cultures, the vitality in African dance and the free expression art form of hip-hop. Seeming to favour works with alternative materials, observers of the work describe it as provocative, volatile and extraordinary due to their subtle incorporation of Paintings, poetry and performance art.

They have had appearances of their designs, Art works, Films and fashions showing at numerous exhibitions and shows in East Africa and abroad, including but not limited to Johannesburg Art fair, South Africa (2015), KLAART Uganda (2014). Deveron Arts Scotland (2014), Institute Buena Bista, Curacao (2014), Future of Africa summit, Paris, France, Minneapolis Institute of Art, USA(2014),World Cultural Forum, Rio de Janeiro, Brazil(2016) (Kampala Art Biennale, 2018)

\section{Conclusion}

It is evident that east African art and design has pervaded and surpassed all colonial, national and international boundaries. The Impact is manifested in the fact that through the years, east African art has become collected artifacts in countries where it has been exhibited such as in: Germany, Scotland, United Kingdom, Netherlands, Brazil, Argentina, France, USA, Canada, Niger, Burkina Faso, Kenya, Tanzania, Rwanda and Uganda and to a large extent the rest of the world.

\section{References}

i. Afriart Gallery. (2019). Afriart Gallery. Retrieved October 30, 2019, from https://www.afriartgallery.org/artists/sanaa-gateja/

ii. africanah.org. (2014, November 25). Archives. Retrieved October 31, 2019, from africanah.org: https://africanah.org/samson-ssenkaaba-xenson/

iii. Agence France Presse. (2018, August 31). World News. Retrieved October 30, 2019, from NDTV: https://www.ndtv.com/world-news/after-painting-and-graphic-design-kenyan-man-becomes-junk-artist1909106

iv. Bell-Roberts, B. (2019). ArtAfrica. Retrieved October 30, 2019, from Art Africa Magazine: https://artafricamagazine.org/something-like-a-constellation-sanaa-gateja-kweta-africa-centre/

v. Bryant, K. (2014, February 6). Retrieved October 30, 2019, from Resilience.org: https://www.resilience.org/stories/2014-02-06/embodying-the-diy-spirit-in-our-creative-projects-part-1-ecofriendly-ethos/

vi. Framer Framed. (2015). Retrieved October 16, 2019, from Framer Framed: https://framerframed.nl/en/mensen/sanaa-gateja/

vii. Gacheru, M. W. (2018, April 20). Life and Style. Retrieved October 30, 2019, from Daily Nation: https://www.nation.co.ke/lifestyle/weekend/Recycled-junk-used-in-artwork/1220-449145675b7 mqz/index.html

viii. Gateja, S. (2015, March 3). Changemakers: Sanaa Gateja. African Voices. CNN. Retrieved October 26, 2019, from https://edition.cnn.com/videos/world/2015/03/30/spc-african-voices-sanaa-gateja-a.cnn/video/playlists/intlafrican-voices/

ix. Kampala Art Biennale. (2018). xenson-znja-2. Retrieved October 30, 2019, from Kampala Art Biennale: https://kampalabiennale.org/xenson-znja-2/

x. Kayem, M. (2018, June 5). Arena for Contemporary African, African-American and Caribbean Art. Retrieved October 22, 2019, from Africanah.org: https://africanah.org/sanaa-gateja-the-bead-king/

xi. Komukama, D. (2018, April 20). Paper Passion. Retrieved October 30, 2019, from Arctic Paper: https://www.arcticpaper.com/Home/Arctic-Paper1/Paper-Passion-Intro/2018/Sanaa-gateja/

xii. Nankinga, L. (2016, November 11). Features- Entertainment. Retrieved October 31, 2019, from Eagle Online: https://eagle.co.ug/2016/11/11/xenson-true-definition-art.html

xiii. Nsubuga, D. (2017, September 8). Arts \& Culture. Retrieved October 31, 2019, from New Vision: https://www.newvision.co.ug/new_vision/news/1461247/art-xenson-starts-discourse-life-struggles

xiv. Victoria and Albert museum. (2005). Retrieved October 15, 2019, from Victoria and Albert museum Website: https://www.vam.ac.uk/articles/a-history-of-jewellery

xv. Whalley, F. (2018, December 22). Magazines. Retrieved October 30, 2019, from The Eats African: https://www.theeastafrican.co.ke/magazine/Santa-comes-with-a-sackful-of-fun/434746-4905892r7lrkxz/index.html

xvi. World Cultures. (2014). National Museums Scotland. Retrieved October 18, 2019, from National Museums Scotland:https://www.nms.ac.uk/explore-our-collections/stories/world-cultures/sanaa-gatejas-bead-workshawl/ 